\title{
Aetiological factors in rickets of prematurity
}

\author{
A R J BOSLEY, E R VERRIER-JONES, AND M J CAMPBELL \\ Department of Child Health, University Hospital of Wales
}

SUMMARY Six very preterm ( $<32$ weeks' gestation) infants who developed late-onset respiratory distress were each matched for sex and gestation with 2 control preterm infants. Radiologically and biochemically the diagnosis of rickets and rachitic respiratory distress seemed clear and the pattern conformed with other reports of the syndrome. The control infants were of similar gestational ages but there was a significantly higher incidence of pre-eclampsia in the pregnancies of index cases. Also significant was a prolonged illness of several weeks' duration in the index cases; this illness was either heart failure due to patent ductus arteriosus or prolonged ventilation in the early weeks of life for apnoeic attacks. Awareness of these 2 aetiological factors shows the necessity of monitoring such infants for evidence of rickets. The use of water-soluble antirachitic prophylaxis such as $1 \alpha$-hydroxyvitamin $\mathrm{D}$ or 1,25 -dihydroxy-vitamin $\mathrm{D}$ is sometimes indicated.

It is well-established that preterm infants have a tendency to develop rickets. ${ }^{1-2}$ Glasgow and Thomas $^{3}$ described a syndrome of late-onset respiratory distress due to rachitic softening of the chest wall occurring in very preterm infants. There are other reports and accounts of preterm babies with bone disease in which the disease seemed to conform to a similar pattern and would appear to be rickets. ${ }^{4-8}$

We have seen 6 such infants in Cardiff, and we feel that they had rickets. Each was extremely preterm and had a similar biochemical and radiological pattern. Details are summarised in the Table and sample $x$-rays are shown (Figs 1, 2, 3, and 4). Three of them developed late-onset respiratory distress of a severe form interfering with their ability to feed. One had profound hypocalcaemia, a very high alkaline phosphatase concentration, and clinically gross tetany (unresponsive to oral supplements). In this infant (Case 1) the respiratory distress occurred

Table Details of 6 infants who developed late-onset rachitic respiratory distress

\begin{tabular}{|c|c|c|c|c|c|c|c|c|c|}
\hline \multirow[t]{2}{*}{ Case } & \multirow{2}{*}{$\begin{array}{l}\text { Gestation } \\
\text { (weeks) }\end{array}$} & \multirow{2}{*}{$\begin{array}{l}\text { Birthweight } \\
(g)\end{array}$} & \multirow{2}{*}{$\begin{array}{l}\text { Complications of } \\
\text { pregnancy }\end{array}$} & \multirow[t]{2}{*}{ Delivery } & \multirow{2}{*}{$\begin{array}{l}\text { Complications in } \\
\text { early infancy }\end{array}$} & \multirow{2}{*}{$\begin{array}{l}\text { Vitamin } D \\
\text { dosage } \\
\text { (IU/day) }\end{array}$} & \multicolumn{2}{|c|}{ Respiratory distress } & \multirow{2}{*}{$\begin{array}{l}\text { Features of the } \\
\text { rachitic respiratory } \\
\text { distress }\end{array}$} \\
\hline & & & & & & & Severity & $\begin{array}{l}\text { Age at onset } \\
\text { (weeks) }\end{array}$ & \\
\hline 1 & 30 & 850 & $\begin{array}{l}\text { Severe } \\
\text { pre-eclampsia }\end{array}$ & $\begin{array}{c}\text { Caesarean } \\
\text { section }\end{array}$ & $\begin{array}{r}\text { Patent ductus } \\
\text { weeks } 4-10 \\
\text { with failure }\end{array}$ & 200 & $+t+$ & 12 & $\begin{array}{l}\text { Tetany; rib fractures; } \\
\text { pulmonary } \\
\text { 'infiltrates' }\end{array}$ \\
\hline 2 & 30 & 1030 & $\begin{array}{l}\text { Severe } \\
\text { pre-eclampsia }\end{array}$ & $\begin{array}{c}\text { Caesarean } \\
\text { section }\end{array}$ & $\begin{array}{l}\text { Ventilated for } \\
5 \text { weeks for } \\
\text { apnoea and } \\
\text { pneumonia }\end{array}$ & 200 & ++ & 7 & $\begin{array}{l}\text { Rib fractures; } \\
\text { pulmonary changes }\end{array}$ \\
\hline 3 & 30 & 1350 & $\begin{array}{l}\text { Severe } \\
\text { pre-eclampsia }\end{array}$ & Vaginal & $\begin{array}{l}\text { Patent ductus } \\
\text { with failure } \\
\text { weeks } 3-9\end{array}$ & 400 & ++ & 12 & $\begin{array}{l}\text { Rib fractures; } \\
\text { pulmonary changes }\end{array}$ \\
\hline 4 & 30 & 1475 & $\begin{array}{l}\text { Severe } \\
\text { pre-eclampsia }\end{array}$ & Vaginal & $\begin{array}{l}\text { Apnoeic attacks } \\
\text { in first } 2 \\
\text { weeks of life }\end{array}$ & 400 & + & 12 & $\begin{array}{l}\text { Rib fractures; } \\
\text { pulmonary changes }\end{array}$ \\
\hline 5 & $27 \cdot 5$ & 750 & $\begin{array}{l}\text { Recurrent } \\
\text { antepartum } \\
\text { haemorrhage }\end{array}$ & Vaginal & $\begin{array}{l}\text { Recurrent } \\
\text { apnoea, } \\
\text { ventilated for } \\
4 \frac{1}{2} \text { weeks }\end{array}$ & 800 & +++ & 6 & $\begin{array}{l}\text { Pulmonary changes } \\
\text { marked }\end{array}$ \\
\hline 6 & 30 & 1030 & $\begin{array}{l}\text { Recurrent } \\
\text { antepartum } \\
\text { haemorrhage }\end{array}$ & Vaginal & $\begin{array}{l}\text { Diabetes mellitus } \\
\text { weeks 2-10. } \\
\text { Required } \\
\text { insulin }\end{array}$ & 200 & $++t$ & 12 & $\begin{array}{l}\text { Rib fractures; } \\
\text { gross pulmonary } \\
\text { changes }\end{array}$ \\
\hline
\end{tabular}




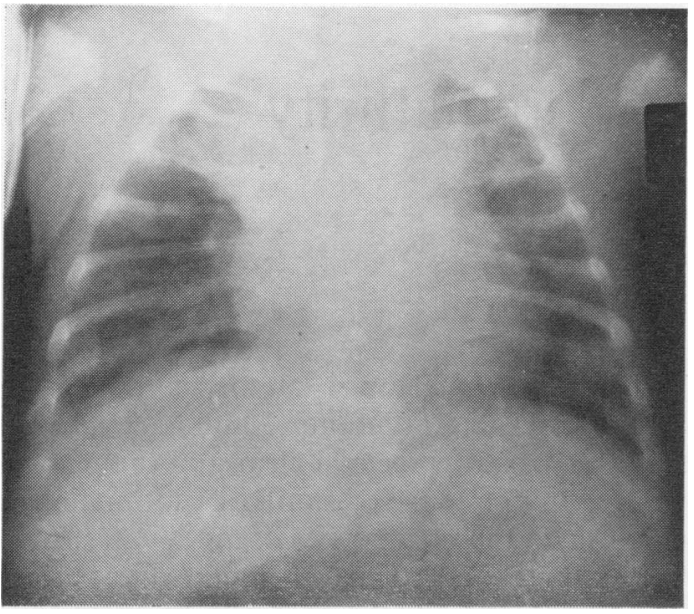

Fig. 1 (Case 1.) Chest $x$-ray at age 12 weeks.

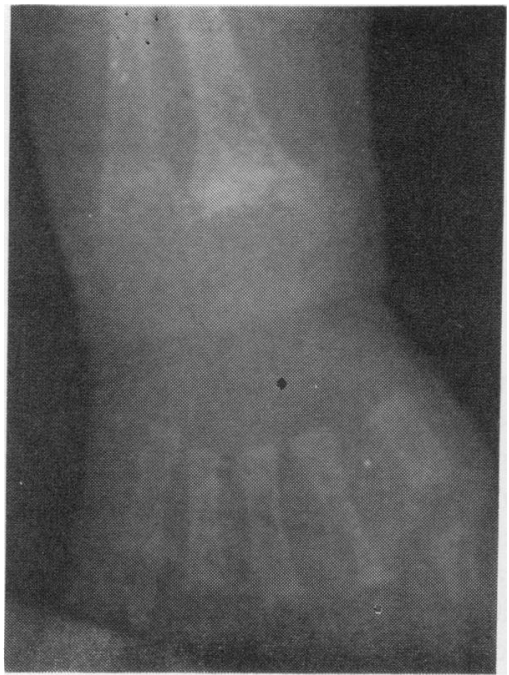

Fig. 3 (Case 1.) X-ray of right wrist at age 14 weeks.

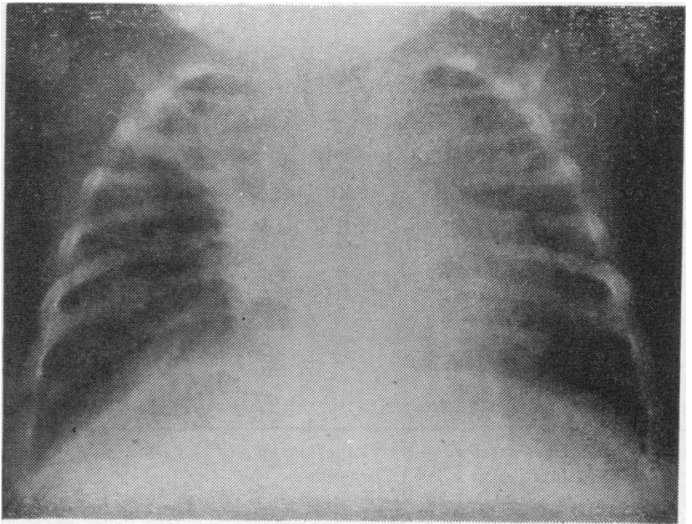

Fig. 4 (Case 6.) Chest $x$-ray at age 12 weeks.

at age 12 weeks and persisted for 4 weeks, as did the hypocalcaemia and tetany. There was no neutropenia to suggest copper deficiency ${ }^{9}$ and magnesium levels were normal $(0.9 \mathrm{mmol} / 1 ; 2.2 \mathrm{mg} / 100 \mathrm{ml})$. $X$-rays of this child's chest showed rib fractures, osteoporosis and pulmonary collapse, and lung infiltrates similar to those described by Glasgow and Thomas. $^{3}$

This syndrome is in our experience occasionally seen in preterm infants despite routine vitamin prophylaxis, and yet no aetiological factors have

Fig. 2 (Case 1.) X-ray of right knee at age 14 weeks. 
been defined. We have used our index cases to try to identify aetiological factors. Each case was matched for gestational age, sex, and period of delivery with 2 controls (for twins, two sets of twins, or if one survivor of twins, then similarly with a single survivor of twins). Possible aetiological factors were compared in the two groups using Pike's method ${ }^{10}$ and Student's $t$ test.

\section{Results}

Six index cases were matched with 12 control preterm infants born in the same period March 1977May 1978 in the same units. The mean gestational age of the index cases was $29.5(\mathrm{SD} \pm 1.02)$ weeks, and that of the controls $29 \cdot 8( \pm 0 \cdot 83)$ weeks. The mean birthweight of the index cases was 1080 $( \pm 256 \cdot 8) \mathrm{g}$, and that of the controls $1267( \pm 232 \cdot 5) \mathrm{g}$. The difference in mean birthweights was not significant $(P>0 \cdot 25)$.

In the two groups, index cases and controls, the following factors were compared: severe preeclampsia (albuminuria, oedema, and diastolic blood pressure $>100 \mathrm{mmHg}$ ), recurrent antepartum haemorrhage, initial respiratory illness (respiratory distress or recurrent apnoea), prolonged illness, initial serum calcium, and initial vitamin $D$ prophylaxis. The prolonged illnesses were heart failure from patent ductus arteriosus ( 3 infants), ventilation for $>4$ weeks for apnoeic attacks and pneumonia ( 2 infants), and neonatal diabetes mellitus (1 infant). In each of these, the illness exceeded 4 weeks in duration and was a major problem of management compromising the infant's survival.

There was no significant difference in the incidence of antepartum haemorrhage, jaundice, initial serum calcium, or initial respiratory illness (respiratory distress or apnoea). The vitamin $\mathbf{D}$ prophylaxis dose was the same in both groups (Abidec multivitamin preparation, Parke Davies).

Significant factors were severe pre-eclampsia in the pregnancy $(5 / 6$ index cases, $1 / 12$ of the controls, $P<0.05)$ and prolonged illness in the infant $(4 / 6$ of the index cases, $0 / 12$ of the controls, $P<0.025)$ using Pike's method for each factor. Therefore preeclampsia in the pregnancy and a prolonged debilitating illness in the infant seemed to be aetiological factors determining the predisposition to rickets. There may be other factors but none was significantly identified in this small series.

The results of this analysis show that very preterm infants with major problems in their management are at risk for developing rickets. The most common illness was heart failure from a patent ductus arteriosus.

\section{Discussion}

There have been many reports of rickets in preterm infants, and recently a report of respiratory distress apparently due to rachitic involvement of the chest wall. Rickets should be a preventable disease, and the fact that infants can develop respiratory distress as a result of this aroused our interest in the aetiology and why it seems to affect only a few infants.

Our 6 infants were all ill with respiratory distress. One had severe tetany and hypocalcaemia very resistant to treatment with calcium. This infant also had pronounced respiratory distress sufficient to compromise her feeding. Two others had a similar degree of respiratory distress and another 2 infants, although very breathless, were tube fed throughout. We found no evidence of infection-haematological, viral, or bacterial - to cause this syndrome.

Our analysis indicates that pre-eclamptic toxaemia is one aetiological factor. Pre-eclampsia would be expected to affect placental function, and Khattab and Forfar ${ }^{11}$ showed that the transfer of calcium to the infant is impaired in pre-eclampsia. Also preeclampsia leads to a degree of hypoxia and starvation which may affect the liver and enzyme systems and perhaps affects the initial hydroxylation of vitamin D3 to 25-hydroxy-vitamin D (25-OHD) taking place in the liver. However, there may be other explanations. These infants had a low dose of vitamin D3 prophylaxis (800 IU or less daily) and it may be that the preterm infant is less able to absorb or hydroxylate vitamin D3 than the mature infant. The serial 25-OHD levels peiformed by Hillman and Haddad $^{12}$ showed that such levels fall in very preterm infants, and later rise when they are gestationally equivalent to 36 weeks' gestation. There are no recent studies to indicate a suitable form or dose of antirachitic prophylaxis; current recommendations of $400 \mathrm{IU} /$ day $^{13}$ were presumably based on early studies. ${ }^{14}$ It is possible that the preterm infant needs either much larger doses of vitamin D3 or perhaps 1,25 dihydroxy-vitamin $D$ instead.

Another factor must be operative however, as not all preterm infants born after pregnancies with severe pre-eclamptic toxaemia go on to develop rickets in early infancy. We think the debilitating illness may be the other contributory influence.

Infants with heart failure from a patent ductus arteriosus may have a congested liver and gut, and therefore a degree of malabsorption and impaired liver function. It would not be surprising to see the metabolism compromised in the sick infant, various enzymes and cofactors could be depleted, and hydroxylation of vitamin D3 to 1,25-dihydroxyvitamin $D$ be thus limited.

As in the infants reported by Davies et al. ${ }^{15}$ and 
Glasgow and Thomas ${ }^{3}$ the vitamin $D$ level at the time of presentation with rickets was not unduly low. In one baby in our series a level was obtained at the time of presentation with late-onset respiratory distress, and was in the low normal range $(15 \mathrm{ng} / \mathrm{ml})$. Nevertheless we feel from our biochemical, radiological, and clinical observations that the infants we describe had rickets, and that their respiratory distress and rib fractures were a feature of this also, as no other explanation for the respiratory features seems to fit. Copper deficiency seems unlikely as no baby showed hypoalbuminaemia or neutropenia, which are features thereof. We hope the 2 aetiological factors we describe will allow babies at risk to be monitored for rickets and that they be given appropriate antirachitic prophylaxis (possibly as 1,25-dihydroxyvitamin D) early in their postnatal life. The only other fact that we noted is that 5 out of our 6 index cases were boys, as were 3 out of the 4 cases reported by Glasgow and Thomas. ${ }^{3}$

We thank Dr Stuart Woodhead for the 25-hydroxyvitamin D assay, Dr Graham Hinde, Consultant Radiologist, University Hospital of Wales, for opinions on $x$-rays, and Mrs Marilyn Morgan for secretarial assistance.

\section{References}

1 Hamilton B. The calcium and phosphorus metabolism of prematurely born infants. Acta Paediatr (Uppsala) 1922; 2: 1-84.

2 von Sydow G V A. Study of the development of rickets in premature infants. Acta Paediatr [Suppl] (Uppsala) 1946; 33: Supplement 2, 122.
3 Glasgow J F T, Thomas P S. Rachitic respiratory distress in small preterm infants. Arch Dis Child 1977; 52: 268-73.

4 Boissière $\mathbf{H}$, Cagnat $\mathbf{R}$, Poissonnier M, d'Angely $\mathbf{S}$. Dystrophie ostéomalacique du prémature. Ann Pediatr 1964; 11 : 367-83.

5 Keipert J A. Rickets with multıple fractured ribs in a premature infant. Med J Aust 1970; i: 672-5.

6 Lewin P K, Reid M, Reilly B J, Swyer P R, Fraser D. Iatrogenic rickets in low birth weight infants. $J$ Pediatr 1971; 78: 207-10.

7 Tulloch A L. Rickets in the premature. Med J Aust 1974; i: $137-40$.

8 Griscom N T, Craig J N, Neuhauser E B D. Systemic bone disease developing in small premature infants. Pediatrics 1971 ; 48: 883-95.

- Cordano A, Baertle J M, Graham G G. Copper deficiency in infancy. Pediatrics 1964; 34: 324-36.

10 Pike M C, Morrow R H. Statistical analysis of patient control studies in epidemiology. Br J Prev Soc Med 1970; 24: $42-4$.

11 Khattab A K, Forfar J O. The interrelationship between calcium, phosphorus, and glucose levels in mothers and infants in conditions commonly associated with 'placental insufficiency'. Biol Neonate 1971; 18: 1-16.

12 Hillman $L$ S, Haddad J G. Perinatal vitamin D metabolism. II. Serial 25 hydroxyvitamin D concentrations in serum of term and premature infants. $J$ Pediatr 1975; 86: 928-35.

13 Corner B D. Prematurity: the diagnosis, care, and disorders of the premature infant. London: Cassell, 1960: 438-40.

14 Davidson L, Merritt K, Chipman S. Prophylaxis of rickets in preterm infants with vitamin D milk. Am J Dis Child 1936; 51: 1-16.

15 Davies D P, Hughes C A, Moore J R. Letter: Rickets in preterm infants. Arch Dis Child 1978; 53: 88-90.

Correspondence to Dr A R J Bosley, Department of Child Health, University Hospital of Wales, Heath Park, Cardiff CF4 4XN.

Received 28 August 1979 